\title{
ANALISIS INTERAKSI KERUANGAN DALAM MENDUKUNG OPTIMALISASI PENGEMBANGAN POTENSI WILAYAH KEPULAUAN
}

\author{
Nasrul Abdullah ${ }^{1}$, Nur Syam², Fadhil Surur ${ }^{3}$ \\ ${ }^{1}$ Jurusan Perencanaan Wilayah dan Kota, Universitas Islam Negeri Alauddin Makassar \\ Email: Nasrulabdullah27@gmail.com \\ ${ }^{2}$ Jurusan Perencanaan Wilayah dan Kota, Universitas Islam Negeri Alauddin Makassar \\ Email:nursyamas@gmail.com \\ ${ }^{3}$ Jurusan Perencanaan Wilayah dan Kota, Universitas Islam Negeri Alauddin Makassar \\ Email: fadhil.surur@uin-alauddin.ac.id
}

\begin{abstract}
ABSTRAK
Interaksi keruangan sangat berpengaruh dalam pengembangan potensi wilayah. Interaksi keruangan terjadi melalui proses komplementaris, transferabilitas dan intervening opportunities kemudian berkembang kearah pembentukan sistem kerja sama antar wilayah. Potensi wilayah di Provinsi Maluku Utara dapat dimaksimalkan dengan meningkatkan hubungan antarwilayah. Penelitian ini bertujuan untuk menganalisis interaksi keruangan dalam mendukung pengembangan potensi wilayah pada Kabupaten Halmahera Barat, Kota Tidore Kepulauan dan Kota Ternate. Tulisan ini menggunakan gabungan pendekatan kuantitatif dengan metode analisis LQ dan analisis gravitasi. Data diperoleh melalui observasi, survai, dan dokumentasi. Hasil penelitian menunjukkan bahwa akumulasi potensi dan permasalahan wilayah sebagai dasar keterkaitan dalam pengembangan wilayah. Selanjutnya interaksi keruangan pengembangan potensi dominan berkembang pada Kota Ternate dan dukungan sarana dan prasarana transportasi yang lebih memadai merekondisi posisi Kota Ternate sebagai wilayah pasar, Kota Tidore Kepulauan dan Kabupaten Halmahera Barat sebagai wilayah pembangkit atau wilayah potensial. Interaksi keruangan yang berlangsung secara fisik, ekonomi dan sosial yang lebih dominan kearah Kota Ternate, dan bersifat timbal balik, menunjukkan disparitas pelayanan antarkota dan antarwilayah dalam satu kesatuan sistem pengembangan potensi wilayah di Provinsi
\end{abstract}

Kata Kunci: Interaksi, Keruangan, kepulauan; Kota Ternate; Halmahera Barat; Kota Tidore

\begin{abstract}
This study aims to analyze spatial interactions in supporting the development of regional potential in West Halmahera Regency, Tidore Islands City and Ternate City. Spatial interactions are very influential in the development of regional potential. Spatial interactions that occur through complementary processes, transferability and intervening opportunities then develop towards the establishment of cooperation systems between regions. This paper uses a combination of quantitative approaches. Data obtained through observation, surveys, and documentation. The accumulation of potentials and regional problems as the basis of the linkages in regional development. Spatial interaction development of dominant potential develops in Ternate City and the support of more adequate transportation facilities and infrastructure reconditions the position of Ternate City as a market area, Tidore Islands City and West Halmahera Regency as generating areas or potential areas. Spatial interactions that take place physically, economically and socially are more dominant towards Ternate City, and are reciprocal, showing disparity in services between cities and between regions within a single system of regional potential development in the Province
\end{abstract}

Keywords: Interaction, Spatial, islands; Ternate City; West Halmahera; Tidore City; 


\section{PENDAHULUAN}

Pembangunan regional yang berimbang merupakan sebuah pertumbuhan yang merata dari wilayah yang berbeda untuk meningkatkan pengembangan kapabilitas dan kebutuhan mereka. Hal ini tidak selalu berarti bahwa semua wilayah harus mempunyai perkembangan, tingkat industrialisasi, pola ekonomi, atau mempunyai kebutuhan pembangunan yang sama. Akan tetapi yang lebih penting adanya pertumbuhan yang seoptimal mungkin dari potensi yang dimiliki oleh suatu wilayah sesuai dengan kapasitasnya. Menurut Murty (2000) menunjukkan bahwa manfaat dari pertumbuhan ekonomi secara keseluruhan merupakan hasil dari sumbangan interaksi yang saling memperkuat diantar semua wilayah yang terlibat. Selanjutnya menurut Myrdal (1957) engan adanya backwash effect perkembangan ekonomi wilayah maju akan semakin meningkat sedangkan wilayah terbelakang akan semakin terpuruk karena terjadinya penyerapan sumberdaya yang berlebihan. Perkembangan wilayah tersebut mengakibatkan peningkatan permintaan akan barang-barang hasil pertanian dan industry rumah tangga dari wilayah terbelakang. Kondisi ini menandakan adanya dalam faktor pendorong bagi perkembangan wilayah terbelakang (Trinada \& Santoso, 2013).

Menurut Hirschman (1970) dalam Kuncoro (2003) menyatakan ahwa perbedaan antar wilayah tersebut yang menjadi hambatan dalam pemerataan pembangunan ekonomi dikarenakan terkonsentrasinya suatu kegiatan perekonomian yang berdampak pada meningkatnya pertumbuhan ekonomi di beberapa wilayah yang memiliki sumber daya alam melimpah. Kekayaan alam yang dimiliki seharusnya dapat menjadi nilai tambah dalam meningkatkan pembangunan ekonomi. Kelebihan yang dimiliki tersebut diharapkan dapat memberikan dampak menyebar (spread effect). Namun kekayaan alam ini tidak dimiliki oleh semua provinsi di seluruh Indonesia secara merata. Keadaan seperti itulah yang menyebabkan timbulnya ketimpangan antar daerah. Interaksi keruangan terjadi melalui proses komplementaris, transferabilitas dan intervening opportunities. Kemudian berkembang ke arah pembentukan sistem kerja sama antar wilayah. Pada dua wilayah yang saling membentuk kerja sama tersebut menciptakan hubungan ketergantungan satu sama lain. Namun pada kondisi tertentu hubungan tersebut dapat menunjukkan ketimpangan jika salah satu dari wilayah yang berinteraksi menunjukkan dominasi dari distribusi barang dan jasa. Prinsip interaksi keruangan merupakan hubungan timbal balik antara dua wilayah atau lebih misalnya: antara kota dan Desa, antara Daerah Industri dan daerah pemasaran, antara daerah yang padat penduduknya dan daerah yang jarang penduduknya (Mustafa, Manaf, \& Salim, 2018).

Undang-Undang Nomor 26 tahun 2007 tentang Penataan Ruang menjelaskan bahwa wilayah adalah ruang yang merupakan kesatuan geografis beserta segenap unsur yang terkait kepadanya yang batas dan sistemnya ditentukan berdasarkan aspek administratif dan atau aspek fungsional. Rustiadi (2011) wilayah dapat didefinisikan sebagai unit geografis dengan batas-batas spesifik tertentu di mana komponen-komponen wilayah tersebut satu sama lain saling berinteraksi secara fungsional. Sehingga batasan wilayah tidaklah selalu bersifat fisik dan pasti tetapi seringkali bersifat dinamis. Komponen-komponen wilayah mencakup komponen biofisik alam, sumber daya buatan (infrastruktur), manusia serta bentuk-bentuk kelembagaan. Maka istilah wilayah menekankan interaksi antar manusia dengan sumber daya lainnya yang ada di dalam suatu batasan unit geografis tertentu. Pengembangan wilayah memandang penting adanya keterpaduan sektoral, spasial, serta keterpaduan antar pelaku pembangunan di dalam dan antar wilayah (Rustiadi, 2011). Keterpaduan antar daerah di wilayah tersebut menuntut adanya keterkaitan fungsional yang sinergis antar kabupaten/kota, Sehingga terjadinya pemerataan pembangunan sesuai dengan potensi yang dimiliki kabuputen/kota di Provinsi Maluku utara. 
Dalam rangka memacu pertumbuhan ekonomi Maluku Utara serta mengoptimalisasikan pengelolaan sumberdaya alam yang berkelanjutan pemerintah setempat mencanangkan kerja sama di tiga kabupaten/kota yaitu, Kota Ternate, Kota Tidore Kepulauan dan Kabupaten Halmahera Barat yang dikenal dengan kawasan "segi tiga emas". Prioritas dalam pengembangan kawasan segi tiga emas yaitu sebagai upaya untuk mendukung keunggulan dan menciptakan akselerasi pembangunan di Provinsi Maluku Utara. Arah Perkembangan Pusat Kota Ternate dari tahun 2000-2015 dominan mengalami perubahan yang signifikan. Dari aspek perkembangan spasial, Kota Ternate saat ini lebih cenderung pada pembangunan secara vertikal. Namun di pusat Kota Ternate juga terdapat pembangunan secara horizontal dengan gaya sentripetal yang berada di Kelurahan Makassar Timur (Umanailo, Franklin, \& Waani, 2017).

Kota Ternate yang memiliki karakter wilayah kepulauan dihuni oleh 212.997 jiwa penduduk dan luas wilayah $110,70 \mathrm{~km}^{2}$ (BPS Maluku Utara Tahun 2015). Sebagai pusat aktifitas ekonomi perdagangan di Maluku Utara, Kota Ternate menjadi tujuan tempat untuk memasarkan hasilhasil pertanian dan hasil alam lainnya yang berasal dari wilayah sekitar serta pasar untuk segala kebutuhan masyarakat, baik dalam lingkup Kota Ternate maupun Provinsi Maluku Utara secara umum. Secara umum aktifitas ruang wilayah yang berlangsung di Maluku Utara lebih cenderung terpusat pada satu titik pusat yakni di Kota Ternate, ketersediaan kebutuhan masyarakat akan pelayanan publik baik ekonomi maupun sosial, dan aspek lainnya mengindikasikan bahwa interaksi antar kabupaten/kota dan wilayah cenderung terpusat pada Kota Ternate. Ketersediaan moda transportasi baik darat, laut dan udara di Kota Ternate yang menghubungkan Kota Ternate terhadap wilayah di sekitarnya sangat berpotensi menciptakan pergerakan arus barang, manusia dan informasi antar wilayah di Provinsi Maluku Utara.

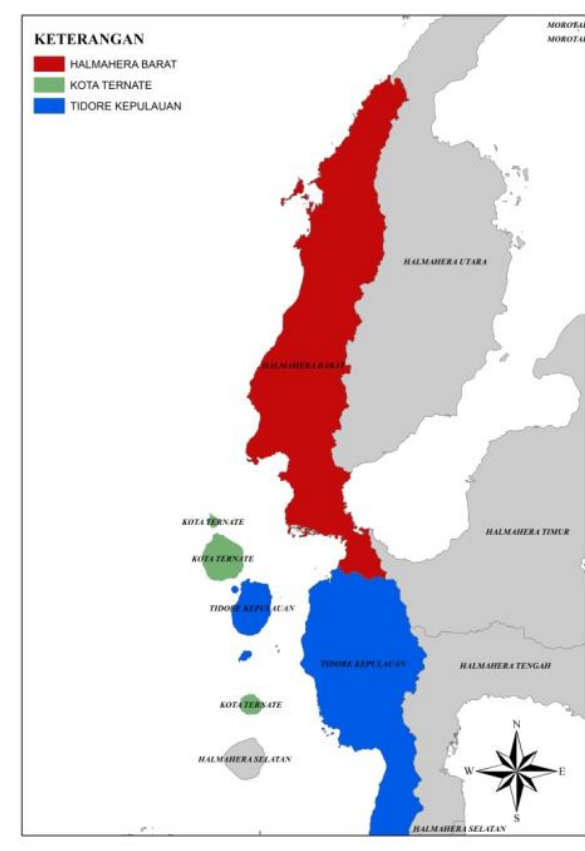

Gambar 1. Peta Orientasi wilayah Sumber : Digitasi GIS

Keberadaan infrastruktur pada kabupaten Halmahera Barat sangatlah penting sehingga mampu mendukung proses pendistribusian di kabupaten/kota di Maluku Utara khususnya akses menuju Kota Tidore Kepulauan dan Kota Ternate. Interaksi keruangan memiliki peran penting dalam 
membentuk struktur ruang yang dikendalikan melalui pola ruang wilayah dalam sistem tata ruang wilayah. Dalam konteks ini sebuah wilayah Provinsi Maluku Utara dapat berkembang dengan seimbang jika interaksi wilayah berjalan sesuai dengan aktivitas masyarakat. Sehingga perlu dilakukan pengkajian tentang Analisa interaksi keruangan dalam mendukung optimalisasi pengembangan potensi wilayah kepulauan di Provinsi Maluku Utara.

\section{METODE PENELITIAN}

\section{Lokasi dan Jenis Penelitian}

Penelitian dilaksanakan di Kabupaten Halmahera Barat, Kota Tidore dan Kabupaten Tidore Kepulauan. Maluku Utara secara geografis adalah daerah kepulauan, letaknya yang strategis berada di bibir pasifik secara global memiliki potensi yang besar. Secara geografis Maluku Utara berada pada 30 LU - 30 LS dan 1240 BT - 1290 BT, berbatasan langsung dengan Samudera Pasifik di sebelah utara, dan laut Seram disebelah selatan, sebelah timur berbatasan dengan laut Halmahera, sebelah barat berbatasan dengan laut Maluku.

Luas wilayah 145.801,10 $\mathrm{km}^{2}$ yang secara administrasi pemerintahan meliputi 2 kabupaten dan 1 kota, Kabupaten Halmahera Utara, Kabupaten Halmahera Tengah dan Kota Ternate. kemudian terjadi pemekaran wilayah pada tahun 2003 dan tahun 2004 yang kemudian dari 3 Wilayah administrasi tersebut menjadi 7 Kabupaten dan 2 Kota, yakni Kab. Halmahera Tengah, kab, Halmahera Timur, Kab. Halmahera barat, Kab. Halmahera Utara, Kab. Halmahera Selatan, Kab. Kepulauan Sula, Kabupaten Pulau Morotai, Kota Ternate dan Kota Tidore Kepulauan Kepulauan. Lokasi penelitiaan ini terdiri dari 3 lokasi yaitu Ternate, Tidore dan Sofifi namun hingga saat ini Sofifi yang merupakan Ibu Kota Provinsi Maluku Utara dan belum dimekarkan dari kota induknya Kota Tidore Kepulauan Kepulauan sebagai Kota Madya, Ibu Kota Provinsi Maluku Utara, sehingga wilayah sofifi masih menjadi bagian dari wilayah administratif Kota Tidore Kepulauan Kepulauan.

Tahapan pengumpulan data mencakup observasi lapangan, wawancara, data instansional dan kepustakaan. Seluruh data yang diperoleh kemudian dikelompokkan berdasarkan kebutuhan data yang digunakan. Batasan data mencakup data kependudukan, data kondisi fisik wilayah dan data penggunaan lahan. Pengambilan data dilakukan pada akhir tahun 2017 dan proses analisa pada tahun 2018. Penelitian ini menggunakan pendekatan kuantitatif dari hasil penelahaan dan pengumpulan data yang dilakukan. Tahapan penelitian merujuk pada metode analisis yang digunakan yaitu:

\section{Analisis Location Quotient (LQ)}

Analisis Location Quotient (LQ) Analisis LQ digunakan untuk menentukan sektor basis dan non basis melalui pendekatan nilai tambah PDRB dan pendekatan jumlah tenaga kerja masingmasing sektor. Dalam penelitian ini peneliti menggunakan pendekatan nilai tambah PDRB dimana rumus yang digunakan adalah sebagai berikut :

$$
\mathrm{LQ}=\mathrm{Vi} / \mathrm{Vt} / \mathrm{Yi} / \mathrm{Yt}
$$

Ket:

$\mathrm{Vi}=$ Nilai PDRB pada sektor I pada tingkat wilayah yang lebih rendah (studi)

$\mathrm{Vt}=$ Total PDRB pada tingkat wilayah yang lebih rendah (studi)

Yi = Nilai PDRB pada sektor I pada tingkat wilayah yang lebih tinggi (referensi) 
$\mathrm{Yt}=$ Total PDRB pada tingkat wilayah yang lebih tinggi (referensi)

Dengan ketentuan bahwa apabila nilai LQ $>1$ maka sektor tersebut merupakan sektor basis yang menjadi kekuatan daerah untuk mengekspor produknya keluar daerah bersangkutan. Sebaliknya jika LQ $<1$ makasektor tersebut menjadi pengimpor atau sektor non basis. Dan jika LQ = 1 maka ada kecenderungan sektor tersebut bersifat tertutup karena tidak melakukan transaksi ke dan dari luar wilayah, namun kondisi seperti ini jarang ditemukan dalam sebuah perekonomian wilayah. Analisis ini bertujuan untuk mengindetifikasi potensi wilayah dari 3 kabupaten/kota yang menjadi kajian penelitian ini.

\section{Analisis Gravitasi}

Dalam menganalisis Model Interaksi keruangan pendekatan untuk menilai hubungan antar daerah adalah Model Gravitasi, Model ini dikembangkan oleh (Hansen, 1959). Nilai potensial atau aksesibilitas dapat menggambarkan adanya potensi aliran antar wilayah. Semakin tinggi nilai potensinya, maka semakin potensial sebagai pusat kegiatan. Sitorus et.al (2012) menyatakan variable yang biasa digunakan untuk analisis model grafitasi antara lain upah, pendapatan dan tingkat pengangguran. Namun variabel tersebut dapat ditambahkan dengan variabel lain yang menggambarkan karakteristik suatu wilayah. Dalam model gravitasi, interaksi antar dua wilayah i dan j dimodelkan sebagai fungsi dari massa kedua wilayah mi dan mj, serta jarak antar kedua wilayah dij, sebagai berikut:

$$
T i j=k \frac{M i^{\alpha} M j^{\beta}}{d i j^{y}}
$$

dimana:

Tij : Interaksi antar wilayah i dan j (perjalanan, arus barang/orang,dll),

mI : massa wilayah i (populasi, PDRB, rasio lahan urban,dll),

mj : massa wilayah j (populasi, PDRB, rasio lahan urban, dll),

rij : jarak antar wilayah i dan j (jarak jalan, waktu tempuh, ongkos perjalanan, dll.

$\alpha, \beta, \mathrm{c}$ : koefisien variabel masa $\mathrm{i}$, massa $\mathrm{j}$ dan jarak $\mathrm{d}$

$\mathrm{k} \quad$ : konstanta.

\section{PEMBAHASAN}

Potensi wilayah Provinsi Maluku Utara pada tahun 2016 didominasi kegiatan pertanian, kehutanan, dan perikanan. Selama kurun waktu 5 tahun, peranan kategori ini terhadap perekonomian Provinsi Maluku Utara mengalami fluktuasi namun terdapat kecenderungan menurun, walaupun pada tahun 2016 mengalami penguatan. Potensi tersebut memberikan kontribusi 26,08 persen pada tahun 2012 sedangkan pada tahun 2016 menurun menjadi 24,96 persen. Penurunan kontribusi kategori Pertanian, Kehutanan, dan Perikanan ini diikuti oleh semakin meningkatnya peranan lapangan usaha sekunder dan tersier (perdagangan dan jasajasa). Kota Tidore Kepulauan sebagai wilayah yang secara administrasi berstatus kota yang berbeda dengan pemerintahan Kota Ternate. Kota Tidore Kepulauan sendiri memiliki luas 155,37 km2 dengan jumlah penduduk sebesar 96.979 jiwa (BPS Maluku Utara Tahun 2015). Selain sebagai pusat perdagangan dan jasa keduanya memiliki potensi perikanan terbesar di Provinsi Maluku Utara. Produksi perikanan laut Kota Ternate mencapai 48.998 ton sedangkan Kota Tidore yaitu 33 472,5 ton. 
Kabupaten Halmahera Barat memiliki luas wilayah 14.823,16 $\mathrm{km}^{2}$, Topografi wilayah didominasi oleh tanah curam yaitu sekitar $62 \%$ dari total daratan. Di wilayah ini terdapat empat gunung berapi yaitu Gunung Jailolo, Onu, Gamkonora dan Tobaru. Jumlah penduduk pada tahun 2015 mencapai 110,000 jiwa atau tumbuh sebesar 1,8\% dari tahun 2014. Potensi pertanian terbesar di Halmahera Barat berasal dari komoditi perkebunan. Sensus pertanian 2013 mencatat jumlah rumah tangga yang mengusahakan tanaman kelapa mendominasi dengan jumlah mencapai 12,76 ribu rumah tangga. Komoditi perkebunan lain banyak diusahakan oleh rumah tangga adalah pala (9,70 ribu rumah tangga), cengkeh $(6,14$ ribu rumah tangga), dan kakao $(1,82$ ribu rumah tangga).

PDRB atas dasar harga berlaku Kota Ternate dari tahun ke tahun terus mengalami kenaikan. Pada tahun 2013 PDRB atas dasar harga berlaku sebesar 1.318.467 juta rupiah, sedangkan PDRB atas dasar harga berlaku pada tahun 2011 sebesar 1.145.574 juta rupiah. Peningkatan ini menunjukkan bahwa terjadi perkembangan perekonomian Kota Ternate. Pada tahun 2013 sektorsektor yang berkontribusi besar terhadap pembentukan PDRB atas dasar harga berlaku yaitu sektor perdagangan, hotel dan restoran sebesar 29,84\%, Sektor jasa sebesar 17,21\%, sektor pengangkutan dan komunikasi sebesar $17,05 \%$ serta sektor pertanian sebesar 12,81\%. Sedangkan di Kota Tidore Kepulauan Kepulauan Nilai PDRB Kota Tidore Kepulauan Kepulauan atas dasar harga berlaku (adhb) tahun 2013 sebesar 640.477,51 juta rupiah, dengan kontribusi terbesar diberikan oleh sektor pertanian yakni sebesar 310.490,67 juta rupiah atau hampir 50 persen dari total pdrb. Sedangkan nilai PDRB atas dasar harga konstan (adhk) tahun 2013 sebesar 322.871,01 juta rupiah dengan laju pertumbuhan ekonomi sebesar 6,11 persen.

Nilai PDRB perkapita Kota Tidore Kepulauan Kepulauan selama tiga tahun terakhir menunjukkan peningkatan tren yang positif. Hal ini memberikan indikasi bahwa perekonomian di wilayah ini menunjukkan tren yang semakin membaik dengan meningkatnya daya beli masyarakat. Setiap sektor dalam menghasilkan Produk Domestik Regional Bruto (PDRB) mempunyai kontribusi yang dapat menggambarkan peran sektor tersebut dalam kegiatan ekonomi suatu wilayah. Jika membandingkan kontribusi setiap sektor terhadap PDRB Kabupaten Halmahera Barat selama 5 tahun terakhir (2010-2014) diperoleh informasi bahwa sektor pertanian masih mendominasi perekonomian Kabupaten Halmahera Barat. Struktur perekonomian Kabupaten Halmahera Barat masih bertumpu pada kategori Pertanian, Kehutanan, dan Perikanan. Kategori ini mempunyai sumbangan terbesar terhadap PDRB tahun 2016. Kategori ini dalam kurun enam tahun terakhir tetap memberikan kontribusi terbesar dengan nilai yang stabil di kisaran 39 persen.

Perkembangan Halmahera barat, Kota ternate dan Kota Tidore Kepulauan dalam dinamikanya menunjukkan bahwa selain faktor kedekatan jarak yang memudahkan pergerakan jasa angkutan transportasi, juga dipengaruhi oleh faktor jumlah penduduk dalam aktifitas ekonomi. Dengan demikian kedua faktor tersebut merupakan determinan yang mendorong proses interaksi keruangan secara fisik, ekonomi dan sosial. Berdasarkan pola pergerakan serta ketersediaan sarana dan prasarana angkutan, menunjukkan bahwa kecenderungan arus pergerakan angkutan cukup tinggi dominan ke arah Kota Ternate jika dibandingkan dengan Kota Tidore Kepulauan dan Halmahera Barat . Artinya, kecenderungan anglomerasi ekonomi yang berkembang pada Kota Ternate, mengondisikan wilayah pasar terbentuk sehingga menjadi motor pengerak interaksi keruangan lebih dominan berkembang kearah Kota Ternate. Realitas ini relevan dengan konseptualisasi teori Dahuri, R. dan Nugroho, I. (2012), bahwa ada dua gejala besar di dalam 
aglomerasi berkaitan dengan wilayah pasar, yaitu; Pertama, bertemunya dua atau lebih aktivitas ekonomi yang berbeda, situasi ini cenderung berkembang pada kota yang berada pada posisi central bussines district (CBD) yang berkonstribusi terhadap perkembangan kota-kota kecil disekitarnya dan membentuk suatu jaringan tertentu sebagai suatu funtional area. Kedua, bertemunya dua atau lebih aktivitas ekonomi yang sama, dalam hal ukuran atau keseragaman wilayah pasar masing-masing produsen sama dan membentuk pasar yang lebih besar secara kumulatif. Kedua faktor tersebut, jika diadaptasikan dalam perspektif interaksi keruangan pada Kota Ternate, Kota Tidore Kepulauan dan halmahera Barat menunjukkan bahwa interaksi keruangan secara fisik, ekonomi dan sosial yang cenderung kearah Kota Ternate sepenuhnya terkondisi akibat sebagai CBD terhadap disekitarnya.

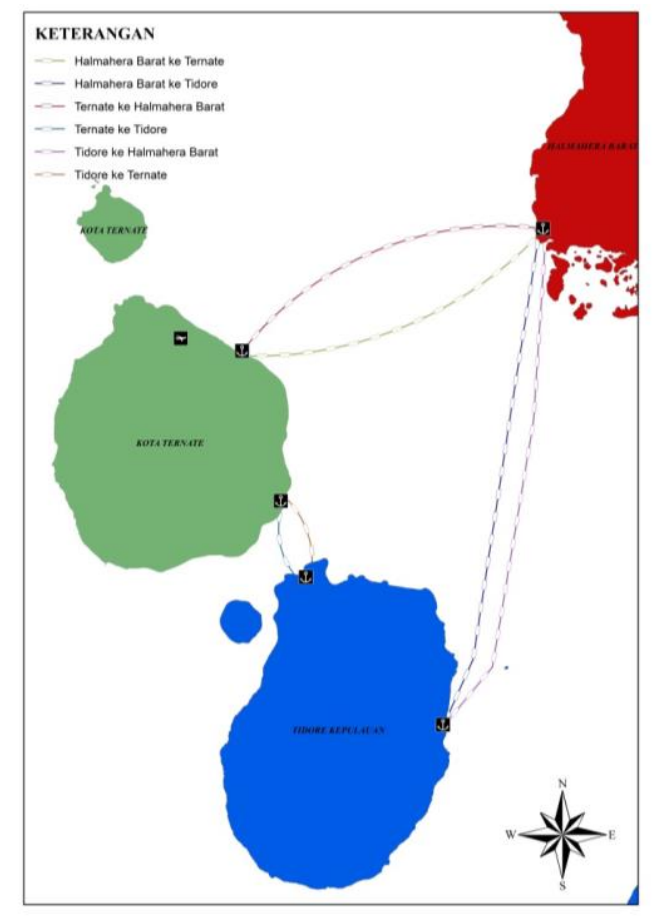
kedudukan Kota Ternate kota-kota kecil

Gambar 2. Peta Pergerakan Barang dan Jasa

Sumber : hasil analisis

\section{Analisis Potensi Wilayah (Sektor Basis)}

Metode pengukuran sektor basis adalah dengan metode location quotient (LQ). Apabila suatu sektor nilai LQ $>1$ maka merupakan sektor basis sedangkan bila LQ $<1$ maka sektor tersebut merupakan non basis. Adapun hasil analisis LQ sebagai berikut :

a. Kota Ternate terdapat 13 (tiga belas) sektor yang menjadi sektor basis yakni : (D) Pengadaan listriuk dan Gas , (F) Konstruksi, (G) Perdagangan Besar dan Eceran, (H) Transportasi dan Pergudangan, (I) Penyediaan akomodasi dan Makan Minum, (J) Informasi dan Komonikasi, (K) Jasa Keuangan dan Asuransi, (L) real Estate, (M) Jasa Perusahan, (O) Administrasi Pemerintahan dan jaminan sosial, (P) Jasa pendidikan, (Q) Jasa Kesehatan dan Kegiatan Sosial, (R) jasa Lainnya Sedangkan sektor yang lain merupakan sektor non basis (sektor pendukung). 
b. Kota Tidore memiliki 7 sektor basis diantaranya ialah (A) pertanian, kehutanan dan perikanan, (D) Pengadaan Listrik dan Gas, (E) Pengadaan Air dan pengoloan sampah, (F) Konstruksi, (M) Jasa Perusahan, (O) Administrasi Pemerintahan, (P) Jasa Pendidikan.

c. Kabupaten Halmahera Barat hanya memiliki 6 (enam) sector basis yaitu (A) pertanian, kehutanan dan perikanan, (C) Industri Pengolahan, (D) Pengadaan Listrik dan Gas, (E) Pengadaan Air dan pengoloan sampah.

Kota ternate merupakan kota dimana perkembangan sector-sektor sangatlah tinggi ini dapat dilihat dari banyaknya sector basis, hal ini berbeda dengan kota Tidore maupun Halmahera barat dimana sector yang bergantung pada sumber daya alam yang lebih dominan.

\section{Anilisis Interaksi Wilayah}

Interaksi antar wilayah (spasial) menggambarkan dinamika yang terjadi di suatu wilayah karena adanya aktivitas yang dilakukan oleh penduduknya, sehingga terjadi mobilitas kerja, migrasi, arus informasi dan komoditas, mobilitas pelajar serta aktivitas ekonomi lainnya.

Tabel 1. Nilai gravitasi di wilayah kajian

Sumber tabel: hasil analisis

\begin{tabular}{ccccc}
\hline No & Wilayah & Model Potensial $(\mathrm{Vi})$ & Model Persaingan Pasar $(\mathrm{Vj})$ & $\mathrm{Vi} / \mathrm{Vj}$ \\
\hline 1 & Kota Ternate & 0.19 & 0.15 & 1.27 \\
\hline 2 & Kota Tidore & 0.32 & 0.33 & 0.98 \\
\hline 3 & Halmahera Barat & 0.49 & 0.52 & 0.94 \\
\hline & Total & 1.00 & 1.00 & Max 3.18 \\
\hline
\end{tabular}

Jika hasil pendugaan parameter daerah asal bernilai lebih besar, maka yang terjadi dalam pola interaksi antara dua lokasi tersebut adalah karena aktifnya daerah produksi. Dalam kasus tersebut di atas terlihat yang menjadi wilayah sebagai pembangkit adalah Kota Tidore dengan nilai 0.32, dan Halmahera barat dengan nilai 0.49. Sedangkan jika hasil pendugaan parameter daerah tujuan bernilai lebih besar, maka yang terjadi dalam pola interaksi dua lokasi tersebut adalah karena aktifnya wilayah pasar. Wilayah yang dikategorikan sebagai wilayah pasar adalah Kota Ternate dengan nilai 0.15 .

Dari model gravitasi di atas terlihat bahwa dinamika interaksi spasial antara Kota Ternate, Kota Tidore dan Kabupaten Halmahera Barat adalah merupakan refleksi dari perubahan PDRB dari tiap wilayah. Implikasinya adalah searah dengan pergerakan arus barang, maka perlu dibangun berbagai infrastruktur pelayanan umum serta yang dapat mendorong pertumbuhan ekonomi wilayah di Ketiga kabupaten/kota sesuai dengan keunggulan wilayah. Potensi penduduk dapat dikaji denganmenggunakan model gravitasi yang mendasarkan pada jumlah penduduk dan jarak antara masing-masing wilayah (Rohani, 2016).

Analisis interaksi atau gravitasi dalam penelitian ini digunakan untuk menilai kekuatan hubungan (kedekatan) antara dua daerah, dimana daerah dianggap sebagai suatu massa yang memiliki daya tarik menarik, sehingga akan muncul hubungan saling mempengaruhi antara kedua daerah tersebut (Rendra \& Fitriansyah, 2020). 
Peningkatan produksi SDA yang tidak diimbangi oleh pertumbuhan pembangunan infrastruktur yang memadai akan mengakibatkan tidak terdistribusinya barang dan jasa dengan baik. sehingga pada akhirnya sumber daya alam khususnya yang menjadi sector basis dapat terkelola dengan baik. Pembangunan infrastruktur yang sesuai dengan karakter sumber daya lokal akan dapat menggerakkan ekonomi sektor riil. Rendahnya produktivitas ekonomi lokal karena tidak ditunjang oleh infrastruktur usaha yang memadai khususnya bagi kegiatan industri pengolahan sektor-sektor unggulan, sementara disisi lain keterbatasan infrastruktur transportasi dan komunikasi akan meningkatkan biaya transportasi dan transaksi yang dapat menurunkan daya kompetitif suatu komoditi.

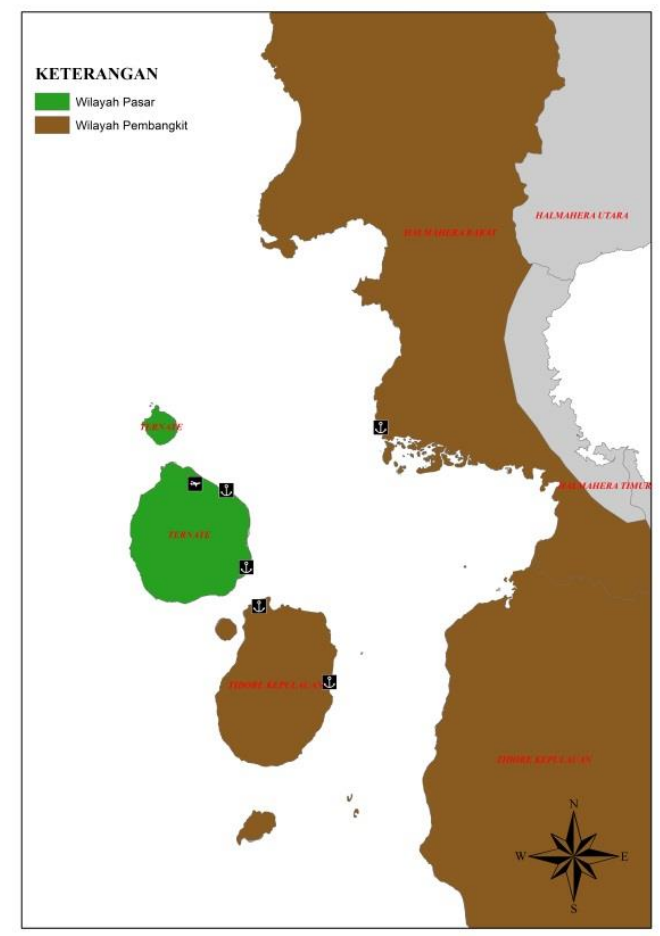

Gambar 2. Peta Wilayah Potensil

Sumber : hasil analisis

\section{KESIMPULAN}

Kota Ternate, Kota Tidore dan Halmahera Barat memiliki berbagai potensi dan permasalahan dalam pengembangan wilayah. Kota Tidore dan Halmahera Barat memiliki struktur ekonomi yang di dominasi oleh sektor pertanian dan perikanan sedangkan sektor yang memberikan konstribusi paling tinggi di Kota Ternate yaitu sektor perdagangan dan jasa namun sector sekunder seperti industri pengelolaan di ketiga wilayah ini masih cukup rendah. Interaksi spasial antara Kota Ternate, Kota Tidore dan Kabupaten Halmahera Barat adalah merupakan refleksi dari perubahan PDRB dari tiap wilayah. Implikasinya adalah searah dengan pergerakan arus barang. Mengembangkan potensi wilayah dengan interaksi keruangan antara Kota Ternate, Kota Tidore dan Halmahera Barat melalui peyediaan sarana prasaranan meliputi moda angkutan laut khusus barang, jaringan jalan yang menghubunngkan daerah hinterland ke daerah base home dan pergudangan serta penguatan pengelolaan sumber daya alam yang mempunyai keterkaitan antar sector di Kota Ternate, Kota Tidore dan Halmahera Barat. 


\section{REFERENSI}

Analisis Pusat Pelayanan dan Inetraksi Keruangan di Kabupaten Bojonegoro. (2020). Jurnal Geografi, 75-82.

Hansen, W. G. (1959). How accessibility shapes land use. Journal of the American Institute of planners, 73-76.

Kuncoro, A. (2003). Microeconomic determinants of economic growth in East Asia. Economics and Finance in Indonesia, 52.

Murty. (2000). Ekonomi Kependudukan. Jakarta: Erlangga.

Mustafa, A., Manaf, M., \& Salim, A. (2018). Interaksi Keruangan Kawasan Perkotaan Tanete dan Implikasinya Terhadap Pelayanan Transportasi. URSJ, 1-9.

Myrdal, G. (1957). Economic Theory and Under-developed regions. Australia: Tylor .

Rendra, M. I., \& Fitriansyah, H. (2020). Analisis Pusat Pelayanan dan Inetraksi Keruangan di Kabupaten Bojonegoro. Geografi UNP, 73-82.

Restuadi, E., \& Panuju, D. R. (2011). Perencanaan dan Pengembangan wilayah. Bogor: Obor Kemajuan.

Rohani. (2016). Analisis Potensi Penduduk dengan Menggunakan Model Gravitasi di Kota Medan. JUPIIS; Jurnal Pendidikan .

Sitorus, S. R. (2012). Analisis Pola Perubahan Penggunaan Lahan dan Perkembangan Wilayah di Kota Bekasi, Provinsi Jawa Barat. Jurnal Ilmu Tanah dan Lingkungan, 21-28.

Trinada, R. A., \& Santoso, E. B. (2013). Penentuan Faktor-Faktor yang Mempengaruhi Ketertinggalan Kawasan Kabupaten Pamekasan. Jurnal Teknik ITS, 226-229.

Umanailo, H. A., Franklin, P. J., \& Waani, J. O. (2017). Perkembangan Pusat Kota Ternate (Studi Kasus Kecamatan Ternate Tengah). Spasial, 222-233. 